\title{
The J-curve: Indonesia vs. Her Major Trading Partners
}

\author{
Mohsen Bahmani-Oskooee \\ The University of Wisconsin-Milwaukee \\ Hanafiah Harvey \\ Penn State University at Mont Alto
}

\begin{abstract}
Couple previous studies that have investigated the J-curve phenomenon for Indonesia, have employed aggregate trade data and provided mixed results. Given the aggregation bias embodied in using trade data between Indonesia and the rest of the world, we disaggregate Indonesian trade data by trading partners and investigate the short-run as well as the long-run effects of the real bilateral exchange rate on the bilateral trade balance between Indonesia and each of her 13 trading partners. We find evidence of the J-curve effect in five out of 13 trading partners.
\end{abstract}

- JEL Classification: F31

- Key Words: Indonesia, trading partners, trade balance, J-curve, bounds testing

\section{Introduction}

One of the policies employed by a country under managed float or fixed exchange rate regime is devaluation. The main objective is to improve the trade

\footnotetext{
*Mohsen Bahmani-Oskooee: Patricia and Harvey Wilmeth Professor of Economics and director of the Center for Research on International Economics at the University of Wisconsin-Milwaukee, Milwaukee, WI 53217, Tel: 414-229-4334, Fax: 414-229-2438, e-mail: bahmani@uwm.edu, Hanafia Harvey: assistant professor in the Department of Economics at Penn State University, Mont Alto, 1 Campus Drive, Mont Alto, PA 17237, Tel: 717-749-6027, Fax : 717-749-6069, e-mail: hhh10@psu.edu. (C2009-Center for International Economics, Sejong Institution, Sejong University, All Rights Reserved.
} 
balance against trading partners. Earlier studies focused on testing the MarshallLerner condition (M-L) according to which for a successful devaluation, the sum of import and export demand elasticities must be greater than one. The ML condition is, however, a long-run condition. Magee (1973) showed that due to adjustment lags, currency devaluation or depreciation could worsen the trade balance before improving it in the long run, hence the J-curve phenomenon. BahmaniOskooee (1985) introduced a method of testing the phenomenon.

There are now two studies that provide a comprehensive review of the literature, i.e., Bahmani-Oskooee and Ratha (2004) and Bahmani-Oskooee and Hegerty (2010). These two studies provide tables that cite main features of every study in the literature and reveal countries for which the hypothesis has been tested at different level of data aggregation. Since this paper is about Indonesia, our search of the literature resulted in three studies that have included Indonesia in their analysis. Indonesia was one the 30 developing countries that was included in Bahmani-Oskooee and Alse (1994) who used Engle-Granger approach to cointegration and error-correction modeling to assess the J-curve using aggregate trade data between each country and the rest of the world. Their unit root tests applied to a measure of the trade balance and the real effective exchange rate of Indonesia revealed that while the trade balance data were stationary, the real effective exchange rate data were non-stationary. Therefore, since both variables were not integrated of the same order, Indonesia was excluded from further analysis. Indonesia was also one of the 7 countries considered by Lal and Lowinger (2002) who used Johansen's cointegration technique to analyze the long run effects of real depreciation and impulse-response analysis to trace the J-curve effect. Again, they employed aggregate trade data between each country and the rest of the world. In the case of Indonesia, the results supported the J-curve effect in the short run but no significant effect in the long run. ${ }^{1}$ The same two methods, i.e., Johansen's cointegration technique and impulse response function were also used by Onafowora (2003) to tackle both issues using bilateral trade data between pair of countries. For each Asian country, the trading partners considered were Japan and the U.S. The results for both Indonesia-Japan and Indonesia-U.S. models supported the J-curve and a significant favorable long-run effect of a real depreciation on both bilateral trade balances.

Given the existing evidence from the above three reviewed studies on unit root

${ }^{1}$ See their Table $2 b$ on page 407. 
Table 1. Indonesia External Trade in 2008 in USD (Million)

\begin{tabular}{crrr}
\hline Trading Partners & Exports & Imports & Trade Balance \\
\hline Australia & 4,365 & 3,981 & 383 \\
Canada & 1,012 & 150 & -497 \\
China PR Mainland & 13,818 & 17,478 & $-3,660$ \\
Hong Kong & 2,192 & 2,141 & 50 \\
Japan & 29,567 & 13,877 & 15,689 \\
Korea & 9,967 & 4,038 & 5,929 \\
Malaysia & 6,813 & 7,900 & $-1,086$ \\
New Zealand & 4,365 & 799 & 3,566 \\
Philippines & 2,436 & 454 & 1,982 \\
Saudi Arabia & 1,236 & 4,415 & $-3,179$ \\
Singapore & 15,993 & 39,321 & $-23,328$ \\
Thailand & 794 & 6,751 & $-5,957$ \\
United States & 15,193 & 6,504 & 8,688 \\
United Kingdom & 2,115 & 794 & 1,321 \\
\hline World & 155,060 & 137,638 & 17,422
\end{tabular}

Source: Direction of Trade Statistics by IMF.

properties of the variables included in the trade balance model of Indonesia, this study goes beyond the existing literature in two directions. First, Pesaran et al.'s (2001) bounds testing approach which does not require pre-unit root testing and variables could be stationary or non-stationary, is employed in this study to assess the short-run as well as the long-run effects of real depreciation of Indonesian rupiah on her trade balance. Second, we consider Indonesia's trade balance on bilateral basis with her 13 major trading partners. These major trading partners possess more than $50 \%$ of the trade with Indonesia. They are listed in table 1 along with their trade shares which reflect relative importance of each partner. The plan of the paper is follows: Section II introduces the model and the methodology. Empirical results are provided in Section III. Section IV provides a summary and finally, the Appendix cites data sources and definition of variables.

\section{The Model and the Method}

In specifying the trade balance model at bilateral level we closely follow the literature like Bahmani-Oskooee and Brooks (1999), Lal and Lowinger (2002), and Onafowora (2003) and adopt the following specification:

$$
\ln T B_{j, t}=\alpha+\varphi \ln Y_{i n d o, t}+\lambda \ln Y_{j, t}+\chi \ln R E X_{j, t}+\varepsilon_{t}
$$


where $T B j$ is a measure of trade balance between Indonesia and trading partner $j$ defined as the ratio of Indonesia's export to country $j$ over her imports from country $j ; Y_{\text {indo }}$ is Indonesia's real income set in index form to make it unit free; $Y j$ is the index of real income of trading partner $j$ and $R E X j$ is the real bilateral exchange rate between Indonesia and trading partner $j$ defined in a way that an increase reflects a real depreciation of the rupiah against the currency of trading partner $j$.

It is anticipated that an estimate of $\varphi$ to be negative, signifying that an increase in Indonesia's income will increase Indonesia's imports. As a result, $T B$ will decrease. Note that as discussed by Bahmani-Oskooee (1986), if an increase in $Y_{\text {indo }}$ is due to an increase in the production of import-substitute goods, then Indonesia may import less as her income increases. This could result in a positive relationship between Indonesia's income and the trade balance. Following similar argument, an estimate of $\lambda$ is expected to be either positive or negative. As for an estimate of $\chi$, if real depreciation of rupiah (i.e., an increase in $R E X$ variable) is to improve the trade balance, we will expect it to be positive.

Estimating equation (1) by any mean yields only the long-run coefficient estimates. Since the J-curve is a short-run phenomenon, we need to incorporate the short-run dynamic adjustment mechanism into equation (1). The common practice is to specify (1) as an error-correction model. We do so following Pesaran et al.'s (2001) Autoregressive Distributed Lag (ARDL) approach as in equation (2) below:

$$
\begin{aligned}
\Delta \ln T B_{j, t}= & \alpha+\sum_{i=1}^{n} \varphi_{i} \Delta \ln T B_{j, t-i}+\sum_{i=0}^{n} \lambda_{i} \Delta \ln Y_{\text {indo }, t-i}+\sum_{i=0}^{n} \chi_{i} \Delta \ln Y_{j, t-i} \\
& +\sum_{i=0}^{n} \xi_{i} \Delta \ln R E X_{j, t-i}+\omega_{1} \ln T B j,_{t-1}+\omega_{2} \ln Y_{\text {indo } t-1} \\
& +\omega_{3} \ln Y_{j, t-1}+\omega_{4} \ln R E X_{j, t-1}+\mu
\end{aligned}
$$

where $\Delta$ is the first-difference operator and $n$ is the lag length. In this set up, the short-run effects of each variable is assessed by the estimates of coefficients assigned to the first-differenced variables. Specifically, the J-curve effect is established if estimates of $\xi$ are negative at lower lags and positive at higher lags. The long-run effects are detected by the estimates $\omega_{2}-\omega_{4}$ normalized on $\omega_{1}$. However, for the long-run coefficient estimates to be meaningful, one must establish joint significance of lagged level variables using the standard $F$ test with new critical values that incorporate integrating properties of each variable. Pesaran 
et al. (2001) provide two sets of critical values, an upper bound and a lower bound. The upper bound critical values are provided by assuming all variables in a given model to be integrated of order one. The lower bound critical values are provided by assuming all variables to be integrated of order zero. They show that the upper bound critical values could also be used in case some variables are integrated of order one and some integrated of order zero. Thus, for joint significance of lagged level variables which implies cointegration, the calculated F statistic must be greater than the upper bound critical values. ${ }^{2}$

\section{Empirical Results}

The error-correction model outlined by equation (2) is estimated between Indonesia and each of her 13 trading partners listed in table 1 using quarterly data that spans over 1974I-2008IV period. ${ }^{3}$ The first question is at what lag orders equation (2) should be estimated? Previous research has demonstrated that the

Table 2. The result of $F$-Test for Cointegration among the Variables of Bilateral Trade Balance between Indonesia vis--vis her Trading Partners

\begin{tabular}{ccccccc}
\hline \multicolumn{6}{c}{ Calculated $F$ statistic for different lag length imposed on the first difference variables } \\
\hline Trading Partners & 2 lags & 4 lags & 6 lags & 8 lags & 10 lags & 12 lags \\
Australia & 2.08 & 2.28 & 2.55 & 3.52 & 3.56 & 2.48 \\
Canada & 3.38 & 2.00 & 1.57 & 3.07 & 4.34 & 2.32 \\
China & 1.62 & 3.01 & 8.07 & 11.35 & 6.21 & 2.84 \\
Hong Kong & 2.92 & 1.85 & 1.58 & 1.86 & 1.52 & 3.56 \\
Japan & 7.62 & 6.07 & 3.96 & 3.53 & 2.31 & 2.59 \\
Korea & 2.41 & 2.84 & 2.23 & 2.33 & 1.19 & 3.11 \\
Malaysia & 5.49 & 5.24 & 5.42 & 5.81 & 2.96 & 1.80 \\
New Zealand & 3.50 & 3.04 & 1.68 & 0.84 & 0.67 & 1.59 \\
Philippines & 5.23 & 3.45 & 2.83 & 2.54 & 2.54 & 2.75 \\
Singapore & 3.88 & 5.10 & 3.38 & 2.70 & 3.73 & 4.55 \\
Saudi Arabia & 1.66 & 1.53 & 2.06 & 2.89 & 4.09 & 1.53 \\
United Kingdom & 5.68 & 6.70 & 3.94 & 4.10 & 2.36 & 2.42 \\
United States & 3.38 & 1.85 & 1.17 & 0.58 & 0.82 & 0.75 \\
\hline
\end{tabular}

Note: The asymptotic distribution of the $F$ statistic is non-standard. The critical value of $F$-statistics for cointegration is 3.52(upper bound) and 2.45(lower bound) [from table CI in Pesaran et.al (2001, pp 300].

${ }^{2}$ For a more detailed and step by step explanations of this approach see Bahmani-Oskooee and Tanku (2008).

${ }^{3}$ Exceptions are noted in the appendix. 
results of the F-test are sensitive to the number of lags imposed on each of the first differenced variable. ${ }^{4}$ To validate this, we begin with two lags and then change the order of lags ranging from 2 to 12 . The results are shown in table 2 .

Given the critical value of 3.52 at the $10 \%$ level of significance, we gather that there are more significant $F$ statistics when 2 lags are imposed on each of the first difference variables ( 5 out of 13 cases). The support for cointegration is reduced to 4 cases (both using 4,6 and 10 lags), 3 cases (8 lags) and further reduced to 1 case (at 12 lags). The results from this initial step are preliminary, as the lags are imposed arbitrarily with no criterion used to search for the optimal length. Thus, following Bahmani-Oskooee and Tanku (2008), we impose a maximum of 12 lags on each first differenced variable and utilize the Akaike's Information Criteria (AIC) in selecting the optimal number of lags. We then calculate the F statistic at optimum lags and report the results in table 3 .

The results from table 3 reveal that there are still five cases in which our calculated F- statistic is greater than its critical value of 3.52 at the $10 \%$ level of

Table 3. The results of $F$-test when lags are selected by the AIC

\begin{tabular}{ccc}
\hline Partner Country & Optimal \# of lags* & Calculated $F$-Statistics \\
\hline Australia & $8,0,7,0$ & 2.53 \\
Canada & $3,3,0,0$ & 3.09 \\
China & $9,9,12,7$ & 5.29 \\
Hong Kong & $4,11,12,0$ & 3.42 \\
Japan & $1,5,5,3$ & 6.87 \\
Korea & $9,4,12,5$ & 2.00 \\
Malaysia & $2,3,4,3$ & 4.68 \\
New Zealand & $9,9,3,0$ & 1.14 \\
Philippines & $9,0,0,0$ & 2.98 \\
Singapore & $12,0,2,0$ & 5.67 \\
Saudi Arabia & $2,3,1,0$ & 1.96 \\
United Kingdom & $4,5,0,0$ & 6.15 \\
United States & $4,11,0,0$ & 1.74 \\
\hline
\end{tabular}

* Note that $(8,0,7,0)$ indicates that the AIC selected 8 lags for $\ddot{A} \log \mathrm{TB}, 0$ lags for $\Delta \log$ Yindon, 7 lags for $\Delta \log \mathrm{Yj}$ and 0 lags for $\Delta \log$ REX. The critical values when there are four variables in cointegrating space are 3.52 at $10 \%$ level of significance and 4.01 at $5 \%$ level of significance.[Pesaran et al.: 2001, p.300, Table 300, table C1, Case III]

${ }^{4}$ On this point see Bahmani-Oskooee and Brooks (1999) and for other applications of this approach see Bahmani-Oskooee et al. (2005), Bahmani-Oskooee and Hegerty (2007), Halicioglu, F., (2007), Narayan et al. (2007), Tang (2007), Mohammadi et al. (2008), Wong and Tang (2008), De Vita and Kyaw (2008), and Payne (2008). 
significance (i.e., in the results for China, Japan, Malaysia, Singapore, and U.K.). If we judge cointegration using only the F test, we should then exclude the lagged level variables from the model of remaining eight countries. However, we will retain them for all countries due to an alternative test for cointegration to be presented later.

We now proceed with our analysis of estimates of optimum models. Since our concern is detecting the J-curve, for brevity we only report the short-run coefficient estimates of the real bilateral exchange rate in table 4 . At the $10 \%$ level of significance, there is at least one significant short-run coefficient in all trading partners except in the cases of Australia, New Zealand, the Philippines, and the U.S.. Therefore, real depreciation of Indonesian rupiah seems to have significant short-run effects in her trade with nine of her trading partners. However, only in the trade with Korea, the short-run coefficients follow the J-curve pattern. If, however, we subscribe to the new definition of the J-curve advanced by Rose and Yellen (1989), i.e., short-run deterioration followed by long-run improvement, then the jcurve is evidenced in the results for Canada, Japan, Malaysia, Singapore, and the U.K. for the real exchange rate carries a positive and significant long-run coefficient (Table 5) in these cases. From the long-run results we also gather that the level of economic activity in Indonesia and in her trading partners are significant determinant of trade balance in almost $50 \%$ of the cases.

Reported in table 4 are additional diagnostics. First, using the long-run coefficient estimates from Table 5 we form an error-correction term ECM. After replacing the linear combination of lagged level variables in (2) by $E C M_{t-1}$ we re estimate each model using the same optimum lags reported in table 3 . A significantly negative coefficient obtained for by $E C M_{t-1}$ not only supports cointegration but also reflects the adjustment of all variables in each model toward their long-run equilibrium (Bahmani-Oskooee and Tanku, 2008). This seems to be the case in the results for all countries (see Table 4) except in Korea and New Zealand. Additionally, the models are also checked for serial correlation among the residuals using the Lagrange Multiplier (LM) test and for misspecification using Ramsey's RESET test (Regression Equation Specification Error Test). While both statistics are distributed as $\chi^{2}$, the LM statistic has four degrees of freedom while the RESET test has only one degree of freedom. Given their critical values reported at the bottom of Table 4, most countries pass both tests.

Finally, again following the literature we tested the stability of the short-run and the long-run coefficients of each optimum model using the well-known CUSUM 
Table 4. Short-run Coefficient Estimates and Diagnostics

\begin{tabular}{|c|c|c|c|c|c|c|c|c|c|c|c|c|c|}
\hline & Australia & Canada & China & $\begin{array}{l}\text { Hong } \\
\text { Kong }\end{array}$ & Japan & Korea & Malaysia & $\begin{array}{c}\text { New } \\
\text { Zealand }\end{array}$ & Philippines & Singapore & $\begin{array}{c}\text { Saudi } \\
\text { Arabia }\end{array}$ & UK & USA \\
\hline$\Delta \log R E X$ & $\begin{array}{c}0.06 \\
(0.36)\end{array}$ & $\begin{array}{c}0.35 \\
(2.46)\end{array}$ & $\begin{array}{c}0.87 \\
(4.09)\end{array}$ & $\begin{array}{c}0.25 \\
(1.97)\end{array}$ & $\begin{array}{c}0.06 \\
(0.41)\end{array}$ & $\begin{array}{c}-3.84 \\
(1.18)\end{array}$ & $\begin{array}{c}1.09 \\
(2.98)\end{array}$ & $\begin{array}{l}-0.03 \\
(0.07)\end{array}$ & $\begin{array}{c}0.44 \\
(1.41)\end{array}$ & $\begin{array}{c}0.31 \\
(2.65)\end{array}$ & $\begin{array}{c}-0.343 \\
(1.721)\end{array}$ & $\begin{array}{c}0.19 \\
(1.95)\end{array}$ & $\begin{array}{c}0.08 \\
(0.90)\end{array}$ \\
\hline$\Delta$ Log REXt-1 & & & $\begin{array}{l}-0.21 \\
(0.91)\end{array}$ & & $\begin{array}{c}0.30 \\
(2.12)\end{array}$ & $\begin{array}{c}0.03 \\
(0.08)\end{array}$ & $\begin{array}{l}-0.71 \\
(1.52)\end{array}$ & & & & & & \\
\hline$\Delta$ Log REXt-2 & & & $\begin{array}{c}0.71 \\
(3.01)\end{array}$ & & $\begin{array}{c}-0.38 \\
(2.67)\end{array}$ & $\begin{array}{c}0.19 \\
(0.57)\end{array}$ & $\begin{array}{l}-0.08 \\
(0.18)\end{array}$ & & & & & & \\
\hline$\Delta$ Log REXt-3 & & & $\begin{array}{c}0.53 \\
(2.28)\end{array}$ & & & $\begin{array}{c}0.66 \\
(1.88)\end{array}$ & $\begin{array}{c}0.71 \\
(1.94)\end{array}$ & & & & & & \\
\hline$\Delta$ Log REXt-4 & & & $\begin{array}{c}0.24 \\
(1.05)\end{array}$ & & & $\begin{array}{c}0.33 \\
(2.50)\end{array}$ & & & & & & & \\
\hline$\Delta$ Log REXt-5 & & & $\begin{array}{l}-0.48 \\
(2.17)\end{array}$ & & & & & & & & & & \\
\hline$\Delta$ Log REXt-6 & & & $\begin{array}{c}0.60 \\
(2.49)\end{array}$ & & & & & & & & & & \\
\hline ECM(-1) & $\begin{array}{c}-0.18 \\
(2.49)\end{array}$ & $\begin{array}{l}-0.30 \\
(3.33)\end{array}$ & $\begin{array}{c}-0.51 \\
(5.65)\end{array}$ & $\begin{array}{c}-0.15 \\
(1.75)\end{array}$ & $\begin{array}{c}-0.39 \\
(5.97)\end{array}$ & $\begin{array}{c}-0.12 \\
(1.38)\end{array}$ & $\begin{array}{l}0.574 \\
(5.49)\end{array}$ & $\begin{array}{c}-0.16 \\
(1.19)\end{array}$ & $\begin{array}{c}0.38 \\
(3.71)\end{array}$ & $\begin{array}{c}-0.34 \\
(3.70)\end{array}$ & $\begin{array}{c}-0.189 \\
(3.04)\end{array}$ & $\begin{array}{c}-0.48 \\
(4.44)\end{array}$ & $\begin{array}{l}-0.23 \\
(2.57)\end{array}$ \\
\hline Adj $R^{2}$ & 0.24 & 0.24 & 0.48 & 0.42 & 0.11 & 0.32 & 0.252 & 0.482 & 0.29 & 0.03 & 0.222 & 0.24 & 0.29 \\
\hline $\operatorname{LM}\left(\mathrm{c}^{2}{ }_{4}\right)$ & 1.620 & 11.43 & 14.52 & 10.99 & 9.87 & 10.9 & 14.33 & 0.734 & 1.66 & 4.80 & 3.899 & 4.34 & 3.91 \\
\hline $\operatorname{RESET}\left(\chi^{2}{ }_{1}\right)$ & 2.00 & 1.79 & 2.34 & 1.54 & 7.51 & 0.46 & 6.43 & 0.044 & 0.16 & 0.32 & 1.921 & 1.42 & 2.28 \\
\hline
\end{tabular}

Note: Figures inside the parentheses below estimated coefficients represent absolute value of t-statistics. At $5 \%$ level of significance, the critical value of ChiSquared with 4 degrees of freedom is 9.49 .The comparable figure with 1 degree of freedom is 3.84 
Table 5. Estimated Long Run Coefficients of Bilateral Trade Balance Model

\begin{tabular}{|c|c|c|c|c|}
\hline Country & Constant & Log YIndo & $\log \mathrm{Y} j$ & Log REX \\
\hline Australia & $\begin{array}{l}-5.17 \\
(1.72)\end{array}$ & $\begin{array}{l}-2.19 \\
(1.49)\end{array}$ & $\begin{array}{c}5.17 \\
(1.73)\end{array}$ & $\begin{array}{c}0.39 \\
(0.49)\end{array}$ \\
\hline Canada & $\begin{array}{l}-10.06 \\
(2.06)\end{array}$ & $\begin{array}{c}0.93 \\
(1.25)\end{array}$ & $\begin{array}{l}-1.87 \\
(0.98)\end{array}$ & $\begin{array}{c}1.19 \\
(2.08)\end{array}$ \\
\hline China & $\begin{array}{c}5.76 \\
(1.70)\end{array}$ & $\begin{array}{l}-0.87 \\
(1.98)\end{array}$ & $\begin{array}{c}0.50 \\
(1.67)\end{array}$ & $\begin{array}{c}0.38 \\
(1.49)\end{array}$ \\
\hline Hong Kong & $\begin{array}{l}16.94 \\
(1.19)\end{array}$ & $\begin{array}{l}-2.82 \\
(1.29)\end{array}$ & $\begin{array}{c}1.54 \\
(0.51)\end{array}$ & $\begin{array}{c}1.73 \\
(1.32)\end{array}$ \\
\hline Japan & $\begin{array}{l}47.20 \\
(5.42)\end{array}$ & $\begin{array}{c}0.99 \\
(5.03)\end{array}$ & $\begin{array}{l}-4.73 \\
(5.51)\end{array}$ & $\begin{array}{c}0.58 \\
(2.90)\end{array}$ \\
\hline Korea & $\begin{array}{l}-16.73 \\
(1.16)\end{array}$ & $\begin{array}{c}1.32 \\
(0.37)\end{array}$ & $\begin{array}{c}3.71 \\
(0.80)\end{array}$ & $\begin{array}{l}-4.14 \\
(1.12)\end{array}$ \\
\hline Malaysia & $\begin{array}{l}-5.02 \\
(2.72)\end{array}$ & $\begin{array}{l}-3.13 \\
(4.55)\end{array}$ & $\begin{array}{c}2.95 \\
(4.55)\end{array}$ & $\begin{array}{c}1.63 \\
(3.82)\end{array}$ \\
\hline New Zealand & $\begin{array}{l}-20.53 \\
(0.61)\end{array}$ & $\begin{array}{l}-1.05 \\
(0.43)\end{array}$ & $\begin{array}{c}2.99 \\
(0.53)\end{array}$ & $\begin{array}{c}0.14 \\
(0.10)\end{array}$ \\
\hline Philippines & $\begin{array}{l}-5.18 \\
(1.58)\end{array}$ & $\begin{array}{l}-0.55 \\
(0.66)\end{array}$ & $\begin{array}{c}1.15 \\
(0.89)\end{array}$ & $\begin{array}{c}1.17 \\
(1.44)\end{array}$ \\
\hline Singapore & $\begin{array}{l}11.42 \\
(3.13)\end{array}$ & $\begin{array}{l}-3.16 \\
(2.74)\end{array}$ & $\begin{array}{c}2.13 \\
(1.95)\end{array}$ & $\begin{array}{c}0.93 \\
(2.70)\end{array}$ \\
\hline Saudi Arabia & $\begin{array}{r}-10.65 \\
(1.11)\end{array}$ & $\begin{array}{c}3.65 \\
(2.69)\end{array}$ & $\begin{array}{l}-4.60 \\
(2.94)\end{array}$ & $\begin{array}{l}-1.81 \\
(1.68)\end{array}$ \\
\hline United Kingdom & $\begin{array}{l}-14.65 \\
(10.28)\end{array}$ & $\begin{array}{c}0.17 \\
(0.44)\end{array}$ & $\begin{array}{c}1.61 \\
(1.54)\end{array}$ & $\begin{array}{c}0.42 \\
(1.97)\end{array}$ \\
\hline United States & $\begin{array}{c}-25.60 \\
(2.66)\end{array}$ & $\begin{array}{c}1.96 \\
(2.91)\end{array}$ & $\begin{array}{c}5.28 \\
(2.84)\end{array}$ & $\begin{array}{c}0.34 \\
(0.80)\end{array}$ \\
\hline
\end{tabular}

Note: Figures in the parenthesis are absolute values of the $t$-ratios.

and CUSUMSQ tests. A common practice is to adhere to a graphical presentation of the tests. However, for brevity while we present the results in the case of her major trading partner, China, in Figure 1, we summarize them for all countries in table 6. All estimated error-correction models seem to be stable, at least using the CUSUM test.

\section{Summary and Conclusion}

Devaluation is one of the macroeconomic policies that is used to improve trade competitiveness. However, its short-run effects are said to be different than its long-run effects. In fact, a country may experience worsening of her trade balance 
Figure 1. Plot of CUSUM and CUSUMSQ statistics for Indonesia vis-à-vis China

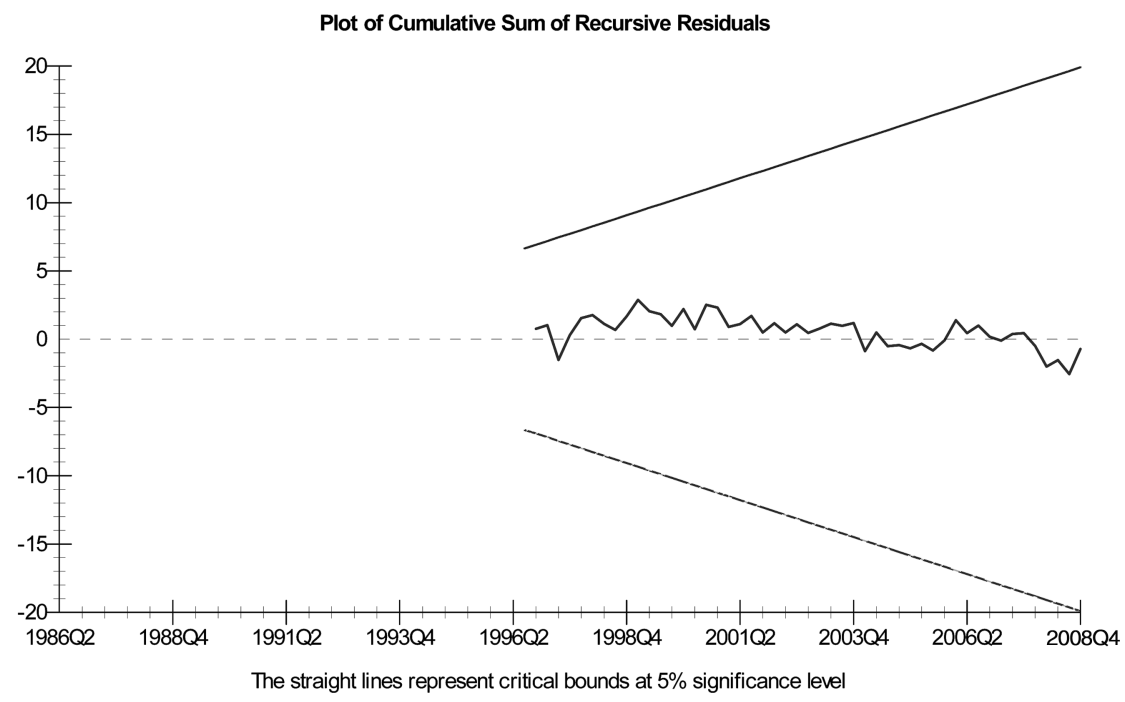

Plot of Cumulative Sum of Squares of Recursive Residuals

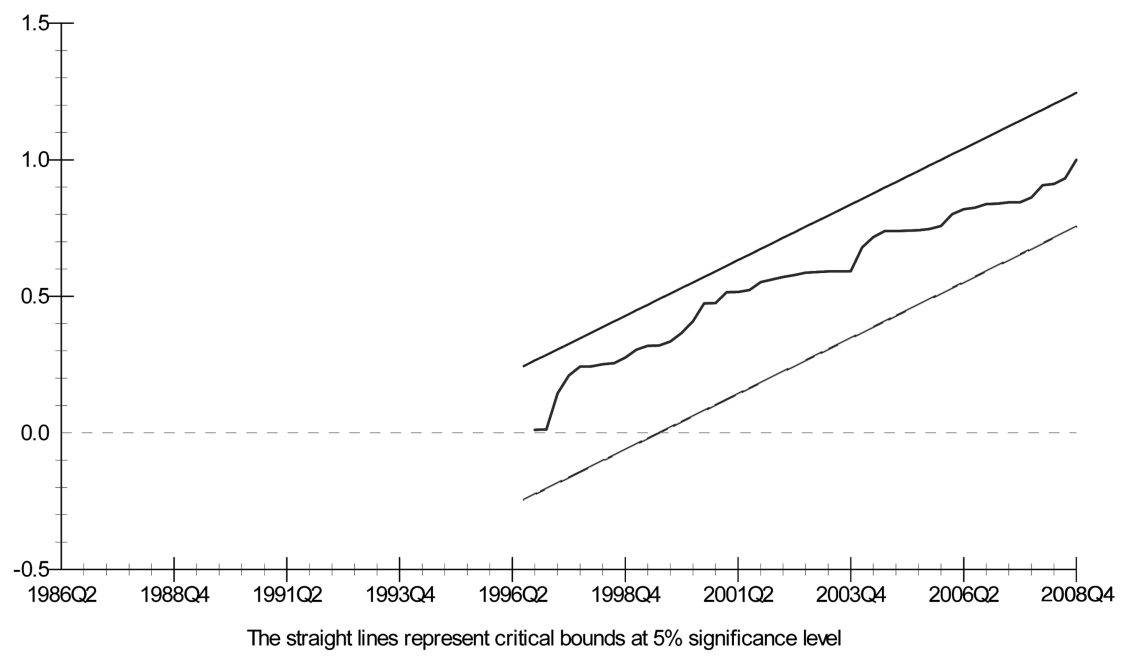

in the short run before any improvement that mostly may come in the long run, hence the J-curve phenomenon. Previous research that examined the experience of Indonesia with depreciation of her currency used aggregate trade data between Indonesia and the rest of the world and provided mixed results.

Suspecting that aggregation bias may mask the significant relation between the effective exchange rate and her trade balance with the rest of the world, in this paper we disaggregated Indonesia's trade data by her major trading partners and 
Table 6. Summary of Stability Test Results for All the Cases

\begin{tabular}{ccc}
\hline Country & CUSUM & CUSUMSQ \\
\hline Australia & Stable & Unstable \\
Canada & Stable & Unstable \\
China & Stable & Stable \\
Hong Kong & Stable & Stable \\
Japan & Stable & Unstable \\
Korea & Stable & Unstable \\
Malaysia & Stable & Unstable \\
New Zealand & Stable & Unstable \\
Philippines & Stable & Unstable \\
Singapore & Stable & Unstable \\
Saudi Arabia & Stable & Unstable \\
United Kingdom & Stable & Unstable \\
United States & Unstable & Unstable \\
\hline
\end{tabular}

examined sensitivity of her bilateral trade balance with 13 major partners. Using quarterly data over the period 1974I-2008IV, application of the bounds testing approach to cointegration and error-correction modeling revealed that while in majority of the cases a real depreciation of rupiah has short-run effects, the shortrun effects last into the long-run favorable effect only in Indonesia's trade balance with Canada, Japan, Malaysia, Singapore, and the U.K.

Received 20 August 2009, Revised 19 October 2009, Accepted 20 October 2009

\section{Appendix A}

\section{Data Definitions and Sources}

\section{A. Data}

Quarterly data over the period 1974:I-2008:IV come from the following sources:

1) Direction of Trade Statistics of IMF, (CD-ROM)

2) International financial Statistics of IMF (CD-ROM).

3) Bank Indonesia, Bank Sentral Republik Indonesia (Central Bank).

Due to unavailability of data on some variables, however, the period was restricted to 1983:I-2008: IV in the case of China; 1977:I-2008:IV in the case of New Zealand; and to 1984:I-2007:IV in the case of Saudi Arabia.

\section{B. Variables}

$T B_{j}=$ Indonesia's trade balance with trading partner $j$ defined as the ratio of 
Indonesia's exports to country $j$ over her imports from country $j$. [Data are collected from source (1)]

$Y_{\text {indo }}=$ Index of Indonesia's real GDP. Data come from source (2).

$Y_{J}=$ Index of Real GDP of partner $j$. Data are from source (2).

$R E X_{j}=$ Bilateral real exchange rate between rupiah and partner $j$ 's currency. It is defined as $\left(P_{j} \times N E X_{j}\right) / P_{\text {Indo, }}$, where $P_{\text {Indo }}$ is Indonesia's CPI, $P j$ is the trading partner's CPI, and $N E X j$ is the nominal bilateral exchange rate defined as the number of rupiah per unit of partner $j$ 's currency. Thus, an increase in $R E X$ is a reflection of real depreciation of the rupiah.

\section{References}

Bahmani-Oskooee, M. (1985), "Devaluation and the J-curve: Some Evidence from LDCs", The Review of Economics and Statistics, 67, p. 500-504.

Bahmani-Oskooee, M. (1986), "Determinants of International Trade Flows: Case of Developing Countries", Journal of Development Economics, 20, pp. 107-123.

Bahmani-Oskooee, M. and Alse, J. (1994), "Short-Run versus Long-Run Effects of Devaluation: Error-Correction Modeling and Cointegration", Eastern Economic Journal, 20, pp. 453-464.

Bahmani-Oskooee, M. and Brooks, T.J. (1999), "Bilateral J-curve between US and Her Trading Partners", Weltwirtschaftliches Archiv, 135, pp. 156-165.

Bahmani-Oskooee, M. and Ratha, A. (2004), "The J-curve: a Literature Review", Applied Economics, 36, pp. 1377-1398.

Bahmani-Oskooee, M. and Hegerty, S.W. (2007), "Exchange Rate Volatility and Trade Flows: a Review Article", Journal of Economic Studies, 34, pp. 211-255.

Bahmani-Oskooee, M. and Tanku, A. (2008), "The Black Market Exchange Rate vs. the Official Rate in Testing PPP: Which Rate Fosters the Adjustment Process", Economics Letters, 99, p. 40-43.

Bahmani-Oskooee, M. and Hegerty, S. (2010), "The J- and S-Curves: a Survey of the Recent Literature", Journal of Economic Studies, forthcoming.

Bahmani-Oskooee, M., Economidou, C. and Goswami, G. G. (2005), "How Sensitive Are Britain's Inpayments and Outpayments to the Value of the British Pound", Journal of Economic Studies, 32, pp. 455-467.

De Vita, G. and Kyaw, K. S. (2008), "Determinants of Capital Flows to Developing Countries: a Structural VAR Analysis", Journal of Economic Studies, 35, pp. 304-322

Engle, R. F., and Granger, C. W. J. (1987), "Cointegration and Error Correction: Representation, Estimation, and Testing”, Econometrica, 55, pp. 251-76.

Halicioglu, F., (2007), "The J-curve Dynamics of Turkish Bilateral Trade: a Cointegration Approach”, Journal of Economic Studies, 34, pp. 103-119.

Lal, A. K. and Lowinger, T.C. (2002), "The J-curve: Evidence from East Asia”, Journal 
of Economic Integration, 17, pp. 397-415.

Magee, S.P. (1973), "Currency Contracts, Pass through and Devaluation", Brookings Papers on Economic Activity, 1, pp. 303-25.

Mohammadi, H., Cak, M. and Cak, D. (2008), "Wagner's Hypothesis: New Evidence from Turkey Using the Bounds Testing Approach", Journal of Economic Studies, 35, pp. 94-106.

Narayan, P.K., Narayan, S., Prasad, B. C., and Prasad, A. (2007), "Export-led Growth Hypothesis: Evidence from Papua New Guinea and Fiji", Journal of Economic Studies, 34, pp. 341-351.

Onafowora, O. (2003), "Exchange Rate and Trade Balance in East Asia: Is There a Jcurve?", Economics Bulletin, 5 (No. 18), pp. 1-13

Payne, J. E., (2008), "Inflation and Inflation Uncertainty: Evidence from the Caribbean Region", Journal of Economic Studies, 35, pp. 501-511.

Pesaran, M. H., Shin, Y. and Smith, R. J. (2001), "Bound Testing Approaches to the Analysis of Level Relationship", Journal of Applied Econometrics, 16, pp. 289-326.

Rose, A.K., and Yellen, J. L., (1989), "Is There a J-curve?", Journal of Monetary Economics, 24, pp. 53-68.

Tang, T.C., (2007), "Money Demand Function for Southeast Asian Countries: an Empirical View from Expenditure Components", Journal of Economic Studies, 34, pp. 476-496.

Wong, K. N. and Tang, T. C. (2008), "The Effects of Exchange Rate Variability on Malaysia's Disaggregated Electrical Exports”, Journal of Economic Studies, 35, pp. 154-169. 